Journal of Thermal Engineering, Vol. 5, No. 3, pp. 181-197, April, 2019

Yildiz Technical University Press, Istanbul, Turkey

\title{
OPERATION OF HVAC SYSTEM FOR ENERGY SAVINGS AND ECONOMIC ANALYSIS
}

\author{
M. Kassas ${ }^{1}$, W. M. Hamanah¹, O. Al-Tamimi ${ }^{1}$, A. Sahin², B. S. Yilbas ${ }^{2, *}$, and C. B. Ahmed ${ }^{1}$
}

\begin{abstract}
In recent years, energy savings in air-conditioning (A/C) systems has become one of the hot topics of applied energy towards innovative management and efficient utilization of the operating systems. Achieving thermal comfort with minimum energy consumption is the main concern for innovative designing of an air conditioning system. The $\mathrm{A} / \mathrm{C}$ system is one of the chief contributors to energy consumption in warm and hot environments. An innovative design of an $\mathrm{A} / \mathrm{C}$ operating system is essential to satisfy a high thermal performance and maintain the desired thermal comfort level. The aim of this work is to introduce innovative design of an operating system to simulate and experiment the thermal performance of $\mathrm{A} / \mathrm{C}$ units for two identical houses located in Dhahran area of Saudi Arabia. In this case, the thermal model for both houses has been developed incorporating two different airconditioning operating systems. In the analysis, several physical properties and parameters, such as climate conditions and heat gain/loss, have been taken into account inside the house. Matlab/Simulink software is used to simulate the ON/OFF and the VFD air conditioning controller systems. LabView platform with the data acquisition is utilized for the experimental work to monitor the real time climate and electrical power data.
\end{abstract}

Keywords: Air-Conditioning, Energy Savings, Variable Frequency Drives VFD, ON/OFF Cycle, Modeling

\section{INTRODUCTION}

Energy savings and efficient utilization of the cooling systems require innovative design of the thermal units that meets the demand with reasonable comfort levels. The performance of variable refrigerant flow systems and best practices for waste energy minimization are the recent interests [1-2] and several approaches were proposed to achieve energy efficient systems [3-6]. On the other hand, many residential areas around the world are characterized by hot and humid atmosphere, such as in the Arabian Gulf, Africa, S America, S. Asia, and part of USA. For example, the primary energy consumption in Saudi Arabia is the HVAC system which accounts for about $60 \%$ of the energy used in the houses [7]. Space-conditioning has gone on the rise throughout the Kingdom of Saudi Arabia (KSA) and also consumption of more energy has increased due to the severe hot temperature, high humidity, and dust storms. The significant focus in designing HVAC systems is ensuring the thermal comfort and reducing the energy consumption. To evaluate the energy consumptions used by the space-conditioning, thermal modeling and simulation of the house must be developed and two types of HVAC system operations will be presented. One HVAC system operates by an ON/OFF cycle and the other HVAC system operates by using a variable speed driver (VFD).

The concept of using simulation as a tool for performance validation and energy analysis of HVAC systems is studied by Salsbury and Diamond [8]. They described one way of making use of new technology by applying simulations configured to represent optimum operation to monitor data. The idea is to use simulation predictions as performance targets with which to compare monitored system outputs for performance validation and energy analysis. They presented results from applying the concepts to a large dual-duct air-handling unit installed in an office building in San Francisco. Muratori et al conducted an estimation of required energy to get a coziness level which was developed by using Matlab/Simulink depending on the predicted temperature variation [9]. They compared their results with the IEA Building Energy Simulation Test (IEA BESTTEST) results. In addition, the results are validated with actual metered residential load data. A simple-physically-based model is used to simulate heating and electric energy consumption throughout the year for domestic HVAC systems. They depend on

This paper was recommended for publication in revised form by Regional Editor Ahmet Selim Dalkilic

${ }^{1}$ Department of Electrical Engineering, KFUPM, Dhahran, Saudi Arabia

2 Department of Mechanical Engineering, KFUPM, Dhahran, Saudi Arabia

${ }^{\star} E$-mail address: bsyilbas@kfupm.edu.sa

Orcid id: 0000-0003-0670-6306

Manuscript Received 23 November 2017, Accepted 2 December 2017 
thermodynamic and heat transfer to regulate air volume in the household. Matlab easily simulates diver scenarios to implement the model. A validation against actual metered residential load data provided by American Electric Power (AEP) is reported by Karmacharya et al [10]. The thermal model of the house is developed by Wen and Burke [11]. They used the autoregressive model with external inputs or with exogenous inputs (ARX model) to obtain the prediction state of the HVAC system. The proposed method is validated by experimentation in a particular home using the GE Nucleus energy management system for data aggregation and algorithm implementation. An ARX model and thermostat regulator is used to simulate and validate their data.

Energy consumption in residential areas is always the main concern and retains a lot of research attention. Zhu has conducted a case study by using a computer simulation code to assess different energy saving approaches. The researcher found that the simulation can offer a reusable tool for energy efficiency researches [12]. Another case study was investigated by Zhou and Park [13] to reduce energy consumption of the building by using the control optimization strategy. Yu et al demonstrated a study for a low energy envelope design of a residential building in the hot summer and cold winter zone in China. They reported that the best energy saving strategy for the HVAC system could be developed through energy modeling to evaluate the effects of envelope design on energy consumption of air conditioners [14]. Nasution et al conducted an experiment for the energy efficiency by using a variable speed driver for a centralized air conditioning system. They controlled the HVAC system using a PID controller as a variable speed compressor and a conventional ON/OFF controller. The energy consumption for both controllers was investigated, and the result shows that an excellent energy saving and temperature control can be achieved by using a variable speed compressor [15].

Thermal analysis of the HVAC system incorporating the ON/OFF controller and the VFD controller are carried out, both experimentally and numerically, to assess the energy consumption of the HVAC system. The experimental set-up with Lab-View based data acquisition monitoring and measurement system is developed while the thermal model and simulation of the house is carried out incorporating different types of A/C system controller (ON/OFF, VFD) units. Predictions of power requirements of the HVAC system are validated through the measurements. Analysis related to the assessment of energy consumption, energy saving, and the cost with the payback period is provided.

\section{ANALYTICAL MOLDING Thermal Model of the House}

In developing strategies to minimize energy consumption in houses, it is crucial to understand the dynamics of working, heat energy generation and losses [16]. This section aims to investigate some of the contributions of heat generation and losses through the developed empirical models. From these models, a thermal model is derived to allow the researcher to build the relationship of heat flows with the variations in temperature [10]. The developed models have adjustable parameters corresponding to different contributions of the heat budget by understanding the form of variation temperatures. Therefore, we aim to determine the most important factors in the energy consumption and production within the house.

The thermal model of a house is presented in Figure $1[17,18]$. The aim of this section is to show the parameters extracted in real-time were a reasonable representation of the house, in that they could be used to control the cooling plant of a real house. This means that, at any instant, the model would have to represent the thermal aspects of a house in its present condition, thus allowing predictions to be made.

The proposed thermal model of the house includes three layers for the wall, roof and windows. The temperature can be found at each desired point on the surface or center of the plaster, concrete, and outside wall of the plaster or stucco. Moreover, using three layers can enhance the thermal house parameters such as the type of building materials and thickness depending on the desired temperature in the house.

Thermal energy absorbed by air in the house, heat transfer via floor, wall and windows are represented in following equations.

$$
Q_{\text {Absorbed in the House Air }}(t)=\frac{\mathrm{dT}_{H}}{\mathrm{dt}} \times C_{\text {Air }}
$$




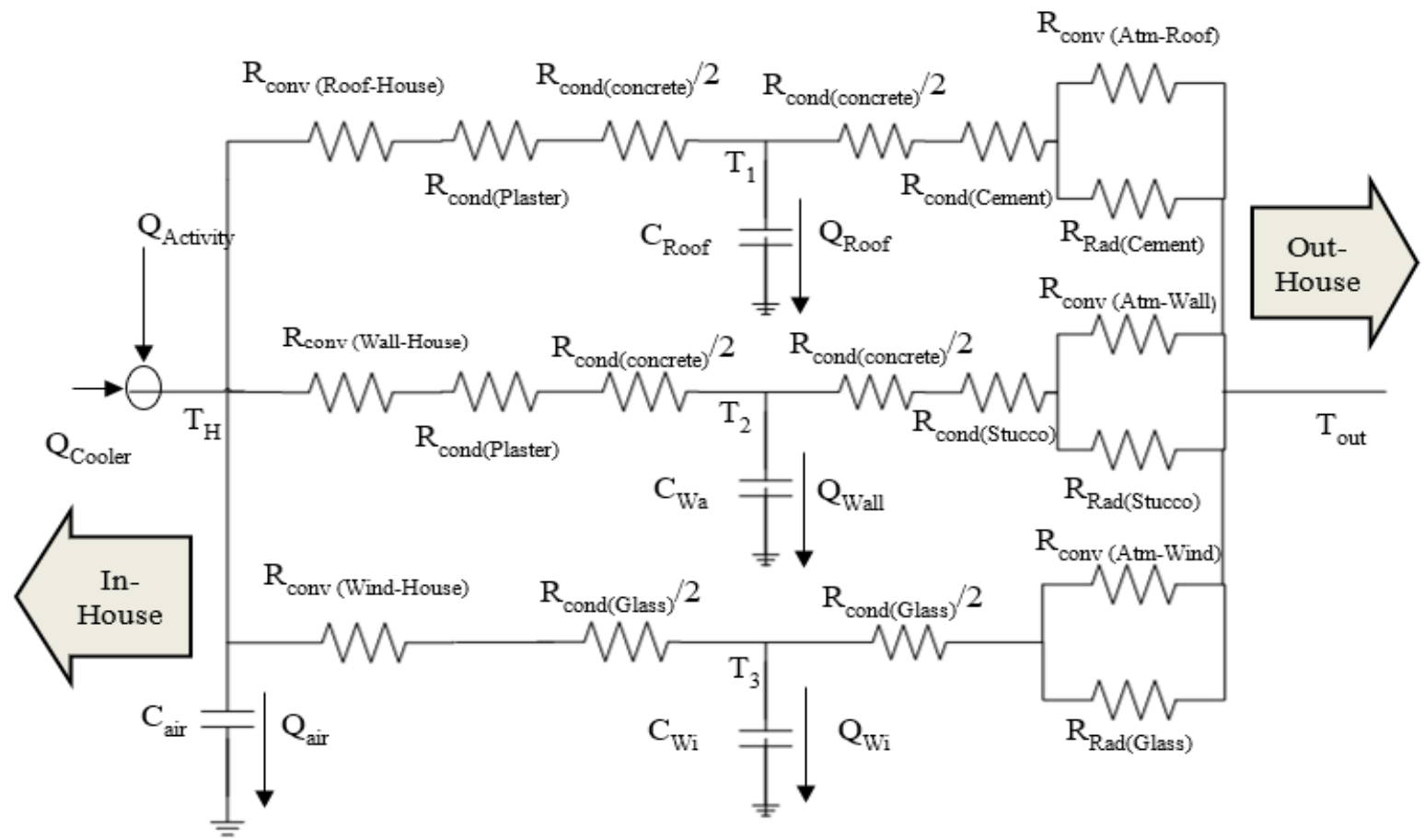

Figure 1. Thermal circuit model of house

$$
\begin{gathered}
Q_{\text {Absorbed in the Roof }}(t)=\frac{\mathrm{dT}_{1}}{\mathrm{dt}} \times C_{\text {Roof }} \\
Q_{\text {Absorbed in the Walls }}(t)=\frac{\mathrm{dT}_{2}}{\mathrm{dt}} \times C_{\text {Wall }} \\
Q_{\text {Absorbed in the Windows }}(t)=\frac{\mathrm{dT}_{3}}{\mathrm{dt}} \times C_{\text {Window }}
\end{gathered}
$$

$Q_{\text {Absorbed in the House Air }}(t)=\left(Q_{\text {Heat Passes to the House }}(t)+Q_{\text {Heat Sources in the House }}(t)-Q_{\text {Cooler }}\right)$ $-\left(Q_{\text {Absorbed in the Roof }}(t)+Q_{\text {Absorbed in the Walls }}(t)+Q_{\text {Absorbed in the Windows }}(t)\right)$

The heat transfer through the roof, walls and windows and the absorbed heat in roof, wall and windows are expressed in the following equations:

$$
\begin{aligned}
& Q_{\text {Heat Passes }}(t)=\underset{\text { the House }}{Q \text { Heat Passes }}(t)+Q \underset{\text { theugh Roof }}{\text { Heat Passes }}(t)+Q \text { Heat Passes }(t) \\
& \underset{\text { Heat Passes }}{\text { though Roof }}=Q_{\text {Absorbed in the Roof }}(t)+U_{11}\left(T_{1}(t)-T_{H}(t)\right) \\
& Q_{\text {Heat Passes }}=Q_{\text {Absorbed in the Walls }}(t)+U_{21}\left(T_{2}(t)-T_{H}(t)\right) \\
& Q \underset{\text { though Windows }}{\text { Heat Passes }}=Q_{\text {Absorbed in the Windows }}(t)+U_{31}\left(T_{3}(t)-T_{H}(t)\right)
\end{aligned}
$$

Finally, the following equations present the thermal model incorporating the parameters related to the house: 


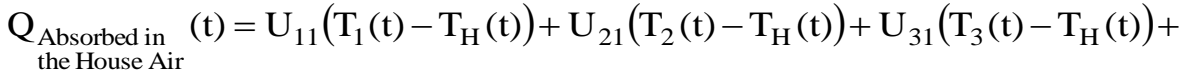

$$
\begin{aligned}
& \mathrm{Q}_{\text {Heat Sources in theHouse }}(\mathrm{t})-\mathrm{Q}_{\text {Cooler }} \\
& \stackrel{\mathrm{T}_{\mathrm{H}}}{(\mathrm{t})=\frac{1}{\mathrm{C}_{\text {Air }}}}\left(\begin{array}{l}
\left(\mathrm{U}_{11} \times \mathrm{T}_{1}(\mathrm{t})\right)+\left(\mathrm{U}_{21} \times \mathrm{T}_{2}(\mathrm{t})\right)+\left(\mathrm{U}_{31} \times \mathrm{T}_{3}(\mathrm{t})\right)-\mathrm{T}_{\mathrm{H}}(\mathrm{t})\left(\mathrm{U}_{11}+\mathrm{U}_{21}+\mathrm{U}_{31}\right) \\
+\mathrm{Q}_{\text {Heat Sources in the House }}(\mathrm{t})-\mathrm{Q}_{\text {Cooler }}
\end{array}\right) \\
& \dot{T}_{1}(\mathrm{t})=\frac{1}{\mathrm{C}_{\text {Roof }}}\left(\mathrm{U}_{12}\left(\mathrm{~T}_{\text {out }}(\mathrm{t})-\mathrm{T}_{1}(\mathrm{t})\right)-\mathrm{U}_{11}\left(\mathrm{~T}_{1}(\mathrm{t})-\mathrm{T}_{\mathrm{H}}(\mathrm{t})\right)\right) \\
& \dot{T}_{2}(t)=\frac{1}{C_{\text {Wall }}}\left(U_{22}\left(T_{\text {out }}(t)-T_{2}(t)\right)-U_{11}\left(T_{1}(t)-T_{H}(t)\right)\right) \\
& \dot{T}_{3}(t)=\frac{1}{C_{\text {Window }}}\left(U_{32}\left(T_{\text {out }}(t)-T_{3}(t)\right)-U_{31}\left(T_{3}(t)-T_{H}(t)\right)\right)
\end{aligned}
$$

\section{Factors Affecting Cooling Load}

The amount of cooling required depends on a large number of factors. These include the dimensions of the house, outdoor temperature, lights, the outdoor humidity, wind speed, the level of insulation in the house, the amount of air leakage in the house, the amount of southern, eastern, and western facing glass in the house, whether this glass is single, double, or triple glazed, and whether window treatments (curtains or blinds) are kept closed or open. Other factors include the amount of shading from trees, roof overhang, awnings, or buildings and how much heat is generated in the house by people during cooking, sleeping and some electric equipments inside the house that produce heat [19].

The operation electrical load by the compressor in one hot day in Dhahran city (KFUPM Campus) has been studied by taking into account the cooling effective factors. Figure 2 shows the outdoor temperatures of the same hot day which is measured for 24 hours. It can be observed that the temperature starts around $35{ }^{\circ} \mathrm{C}$, and it goes up dramatically to $51{ }^{\circ} \mathrm{C}$ at midday, and then it drops slowly until it reaches to $33{ }^{\circ} \mathrm{C}$ at midnight. Figure 2 also presents the daily internal heat load for one hot day in the house as there are only two people living in it.

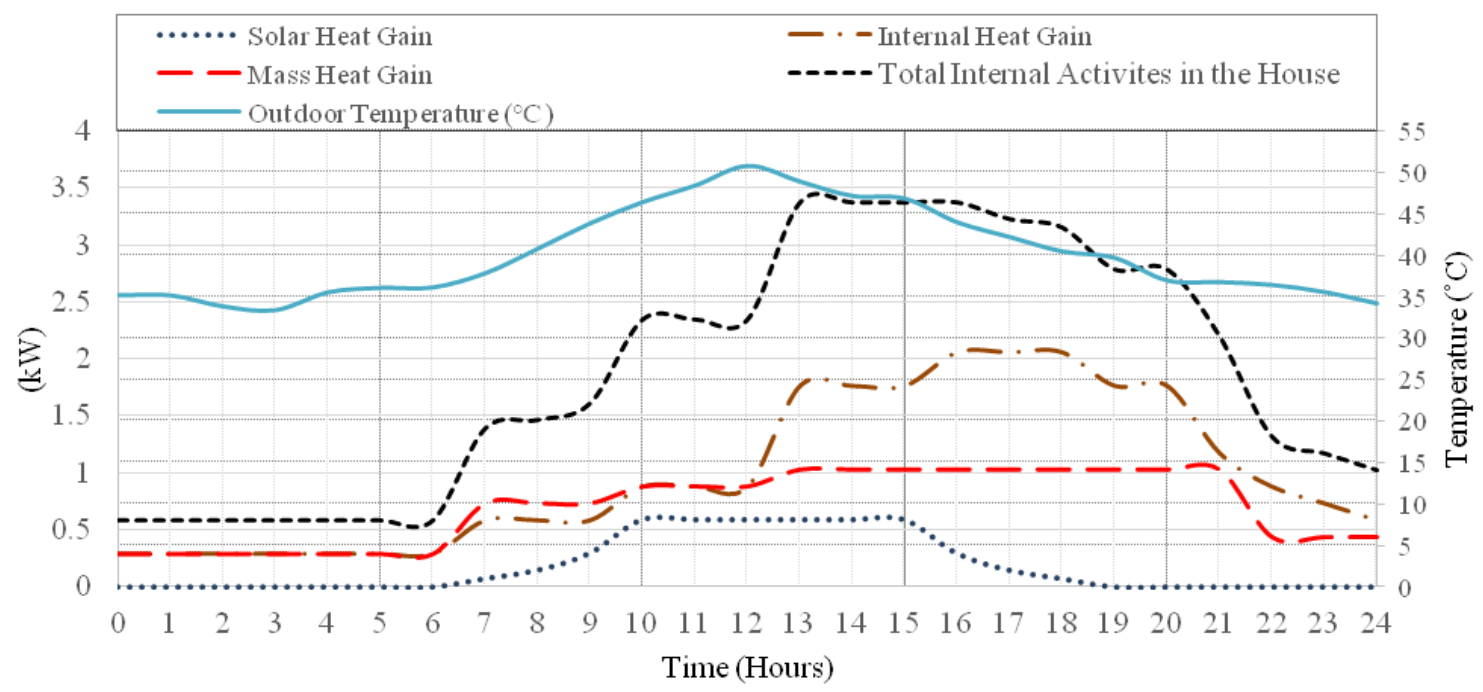

Figure 2. Outdoor temperature with daily internal heat load 


\section{House Thermal Model Using Simscape Physical System}

The thermal model of both identical houses is built by applied Simscape Physical components in Simulink/Matlab as shown in Figure 3. The model is developed with four thermally distinguishable parts: inside air, house walls, windows, and roof. The house exchanges heat with the environment through its walls, windows, and roof. Each path is simulated as a combination of a thermal convection, thermal conduction, and thermal radiation. This model has been integrated with two different units of an air conditioning system; the 1st house has been equipped with VFD HVAC unit and the $2^{\text {nd }}$ house has been equipped with an ON/OFF HVAC unit.

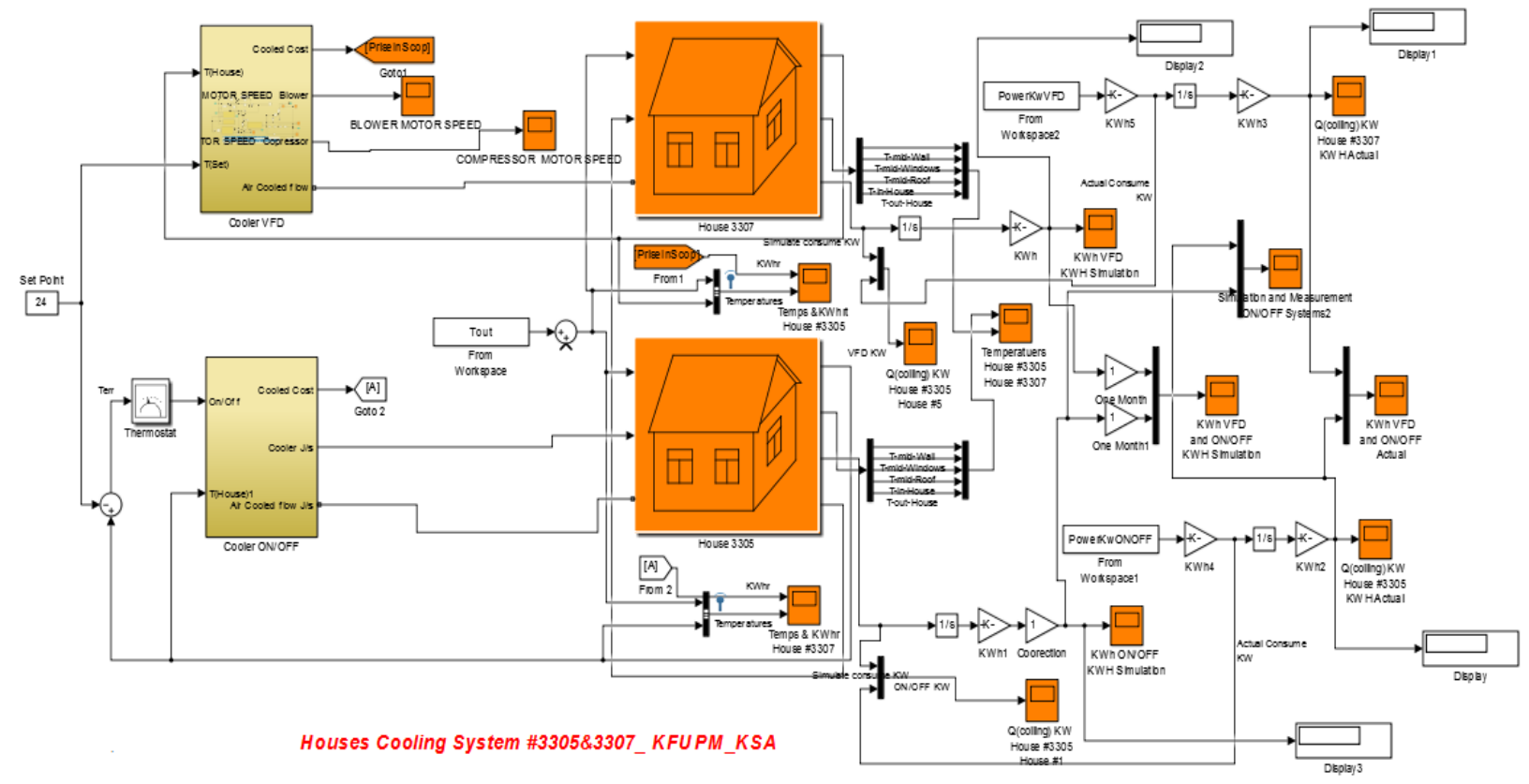

Figure 3. House thermal model integrated with the VFD \& ON/OFF HVAC system using simscape physical components

\section{Conventional A/C System (On/Off Cycle)}

The air conditioning unit attains the desired temperature based on the temperature set by its thermostat. When the compressor of the air conditioner is turned $\mathrm{ON}$, it remains on until the room temperature decreases to the desired temperature on the thermostat. Once the desired temperature is reached, the compressor turns OFF until the room temperature increases again.

The cooling unit is a subsystem that has a constant air flow rate, " $\dot{\mathrm{M}}$ ". The thermostat signal turns the cooler ON or OFF. When the cooler is ON, it absorbs hot air at a temperature (for example 10 degrees Celsius $=50$ degrees Fahrenheit by default) at a constant flow rate (for example $1 \mathrm{~kg} / \mathrm{sec}=3600 \mathrm{~kg} / \mathrm{hr}$ by default). The cool airflow is expressed by the equation (15).

$$
\frac{\mathrm{dQ}_{\text {Cooler }}}{\mathrm{dt}}=\left(\left(\mathrm{T}_{\mathrm{HVAC}}-\mathrm{T}_{\mathrm{House}}\right) \times \stackrel{\bullet}{\mathrm{M}_{\mathrm{HVAC}}} \times \mathrm{C}_{\mathrm{P}}\right)
$$

\section{Variable Frequency Drive A/C Systems}

The Variable Frequency Drive (VFD) has been widely used in the HVAC application, including fans, pumps, compressors, etc. A better understanding of the VFD will lead to improved application and selection of both equipment and HVAC systems. A Variable Frequency Drive (VFD) is a type of adjustable speed drive used to control the speed of the motor based on the system load requirements and operation schedule, resulting in a dramatic cut in 
energy consumption [20]. VFD technology allows the air conditioner to automatically vary its power output to specifically maintain room temperature at a desired or comfortable level. A non-inverter appliance maintains the temperature by repeatedly switching the power ON and OFF, which consumes much more electrical energy upon starting.

The VFD cooler has two options; constant value and variable air flow rate, " $\dot{M}_{\text {HVAC }}(\mathrm{t})$ ". Based on equation 16, the variable airflow rate is delivered from the cooler system using a PI system. The air specific heat is multiplied with airflow rate to produce cooler gain by equation 17 . The HVAC coil temperature ( $\mathrm{T}_{\mathrm{HVAC}}$ ) uses variable values that are controlled by the PI system. Equation 18 is used to calculate the absorbed heat by the air in the house. In the second subsystem equation $19, \mathrm{~T}_{\text {House }}$ and $\mathrm{T}_{\text {Setting }}$ are the inputs signal for the HVAC coil temperature subsystem and the cooling air flow subsystem. The cooling airflows $\left(\mathrm{Q}_{\text {Cooler }}\right)$ into the house are produced from the difference between indoor temperature ( $\left.\mathrm{T}_{\text {House }}\right)$ and the HVAC coil temperature $\left(\mathrm{T}_{\text {HVAC }}\right)$ and then multiplied by cooling gain.

$$
\begin{gathered}
\mathrm{M}_{\mathrm{HVAC}}=\mathrm{K}_{0} \frac{\mathrm{d}\left(\mathrm{T}_{\text {setting }}-\mathrm{T}_{\text {House }}(\mathrm{t})\right)}{\mathrm{dt}}+\mathrm{K}_{1} \mathrm{~T}_{\text {House }}(\mathrm{t}) \\
\text { Cooler Gain }(\mathrm{t})=\mathrm{M}_{\text {HVAC }}(\mathrm{t}) \times \mathrm{C}_{\mathrm{P}} \\
T_{\text {HVAC }}=K_{2} \frac{d\left(T_{\text {setting }}-T_{\text {House }}(t)\right)}{d t}+K_{3} T_{\text {House }}(t) \\
\frac{\mathrm{dQ} \text { Cooler }}{\mathrm{dt}}=\left(\mathrm{T}_{\text {House }}-\mathrm{T}_{\text {HVAC }}\right) \times \text { Cooler Gain }(\mathrm{t})
\end{gathered}
$$

\section{EXPERIMENTAL ANALYSIS Experimental Setup}

The major role of the experimental work in this study is to confirm the validly of the simulation work, and to evaluate the performance and energy consumption of the $\mathrm{A} / \mathrm{C}$ systems. The monitoring and measurement hardware system is comprised of four major blocks: two 5-ton Al-Zamil rooftop units, a Data Acquisition (DAQ) chassis with National Instrument modules (Lab-View), sensors, and a host computer. The National Instrument DAQ-chassis monitoring system has several modules such as voltage measurements, current measurements, and thermocouples. There are four thermocouple sensors (three sensors for indoor and one for outdoor temperature), two humidity sensors (indoor and outdoor), an irradiation sensor, barometric pressure sensor, and three air flow sensors. The host computer has the National Instrument (NI) software, which is the main communicator with DAQ-chassis. The host computer will initiate the execution commands, store the data and display them on the monitor.

\section{Experiment Procedures}

The experiments were conducted in the Guest Houses in KFUPM campus, Dhahran, Saudi Arabia. The floor plan and the duct plan are shown in Figure 5.a. Each house consists of two rooms (one living room and one bedroom), kitchen and bathroom. Moreover, all details of the houses which are integrated with ON/OFF and VFD HVAC systems are described in this section and followed by a HVAC monitoring and measurement system. 


\section{Sensors Location in the Houses}

Different types of sensors have been chosen and placed in both houses to read and measure the required data for the experiment, Figure 4.b, and provide the location of each sensor in the house. Three thermocouple sensors are fixed in the bedroom, corridor and living room. The temperatures are measured from three positions and then we take the average temperature for a house. Airflow sensors are located near inlet air ducts to measure A/C unit flow in kilogram per second. A pressure sensor is also placed inside the house to measure in-house pressure. A thermocouple sensor and an irradiation sensor are placed on the roof of the house to measure the ambient temperature in degree and daily irradiation in watt per meter square.

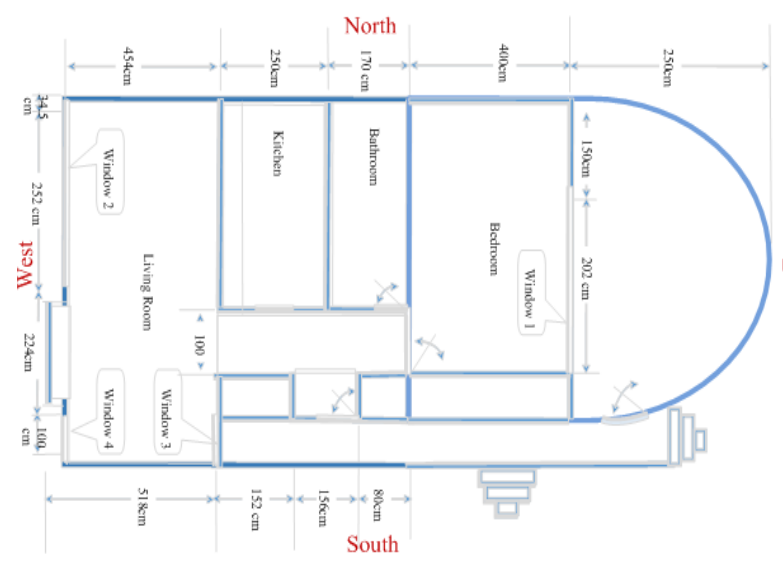

(a)

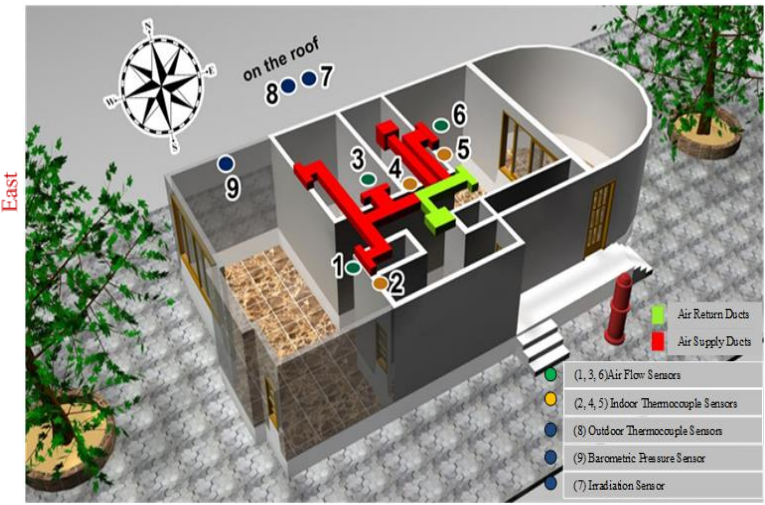

(b)

Figure 4. (a) Floor plan for both houses, (b) Ducts plan and sensor's locations in the houses

\section{Monitoring and Measurement Systems}

The monitoring and measurement systems for both units have been developed to achieve different tasks such as displaying several physical and electrical characteristics, as well as environmental conditions. Furthermore, the data acquisition systems incorporate signals, sensors, actuators, signal conditioning, data acquisition devices, and application software. The purpose of data acquisition system is to measure the electrical or physical parameters such as voltage, current, temperature irradiation, humidity, pressure, and wind speed. The PC-based data acquisition system uses a combination of modular hardware, application software (Lab-View), and a computer to take measurements [21]. Figure 5 shows the drawing map of the monitoring and measurement system.

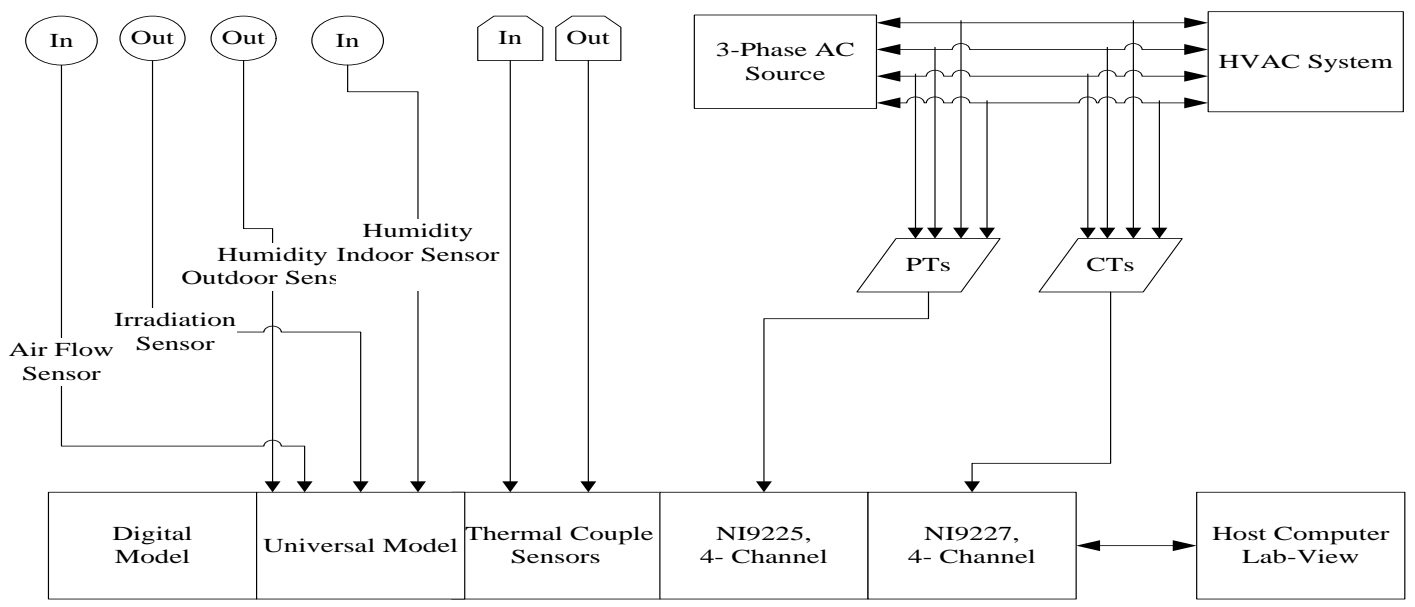

Figure 5. HVAC monitoring and measurement system 
The superimposed graph displayed in Figure 6.a shows the instantaneous values of four temperatures and pressure with time and Figure 6.b displays the instantaneous values (peak to peak) of line voltage with corresponding RMS values.

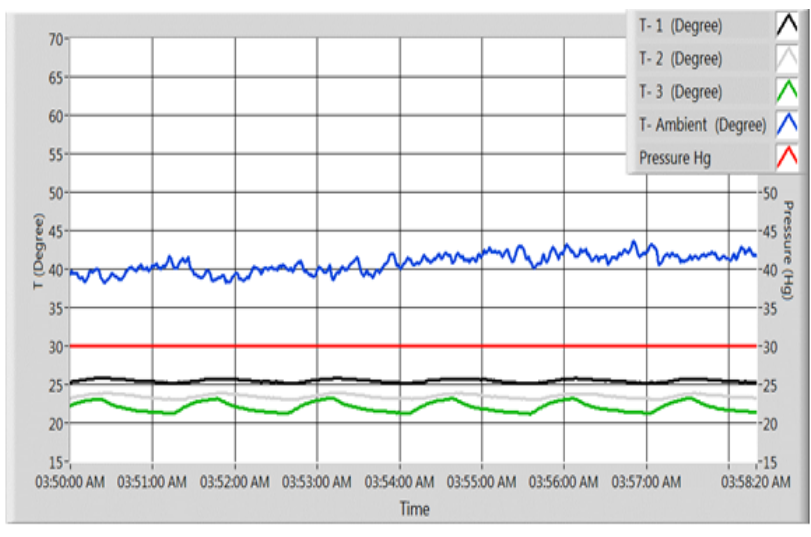

(a)

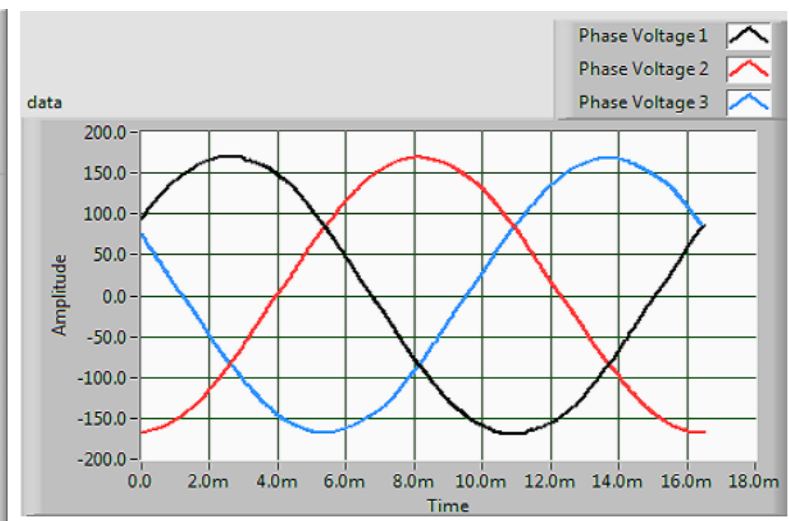

(b)

Figure 6. (a), (b), Monitoring and measurement system (Lab-View Platform)

\section{RESULTS AND DISCUSSION}

In this section, the results for the simulation model with validation against the measuring data are provided and the monthly results for variations of the energy consumption, energy savings, and COP variation have been expressed. In addition, the cost analysis of both the ON/OFF and the VFD HVAC system with payback period for each unit have been calculated.

\section{Validation of the Simulation Results with Measurement Data for Both HVAC Systems}

Simulation results for in-house air temperature and power consumption for one typical day, with normal activities, ( $9^{\text {th }}$ of April 2016) have been presented using Simulink/Matlab. The normal internal activities of the house are shown in the Figure 2. The simulation results are produced for ON/OFF and VFD air conditioning units. Measurement data are collected by Lab-View program for both residential houses. These data are validated with the simulation results for both in-house air temperature and power consumption. Set point temperature is $24{ }^{\circ} \mathrm{C}$ with a threshold $\left(+1^{\circ} \mathrm{C} \&-1.5^{\circ} \mathrm{C}\right)$ and the initial house air temperature is $24.1^{\circ} \mathrm{C}$.

\section{Typical Day Activities (April 9, 2016) for the On/Off Cycle A/C Unit}

Typical day activities validation for indoor temperature is shown in Figure 7. Simulated results are closely following the measurement results where the number of pulses is also equal to 53. The average cycle period is also identical, and the ON-time operation obtained by simulation and measurement are the same $(451.05 \mathrm{~min}=7.5175 \mathrm{~h})$. The outdoor air temperature affects directly the ON/OFF A/C unit as well as the ON pulse numbers. The outdoor temperature as shown in Figure 7 is still constant and equal to $23{ }^{\circ} \mathrm{C}$ from midnight to 6:00 $\mathrm{AM}$ and then it increases dramatically to $42.5^{\circ} \mathrm{C}$ at $12: 30 \mathrm{PM}$. The temperature decreases again slowly to reach $27.5^{\circ} \mathrm{C}$ at $7: 30 \mathrm{PM}$. The house has permanent activities (fridge, computer, monitor, Wi-Fi, lights, and printer) and variable activities (cooking, washing machine, open/close door and windows, etc.).

The activities of heat losses begin at $1.087 \mathrm{~kW}$ and goes up to reach $1.27 \mathrm{~kW}$. Then it goes down to $0.87 \mathrm{~kW}$ as the outdoor temperature stays at $23{ }^{\circ} \mathrm{C}$. From 2:30 AM to 4:00 AM, a decrease is observed in duty cycle that is affected by outdoor temperature reduction to $21^{\circ} \mathrm{C}$ as well as a reduction in in-house activities. While the outdoor temperature increases from 05:30 AM to 10:00 AM, the duty cycle is still low, and it is affected directly by the tree's shadow that is close to the east window of the house. From 10:00 AM to 6:00 PM, the ON/OFF frequency increases due to the increase in the outdoor temperature that reaches $42.5{ }^{\circ} \mathrm{C}$ at midday. The social activities (lunch, dinner, washing machine, open/close windows and door, etc.), increase the duty cycle. The ON/OFF frequency again 
decreases slowly as a result of the outdoor temperature reduction to $26^{\circ} \mathrm{C}$ and some of the social activities (cooking dinner, boiling tea water, etc.), so the duty cycle decreases slowly again.

The simulation and the measurement of the power consumption for the ON/OFF cycle unit on April 9, 2016 are presented in Figure 8. The simulated results are similar to the measurement results (4.95 kW rated value), where the number of the ON/OFF pulses are also equal (53 pulses). The OFF time is $(989.112 \mathrm{~min}=16.4852 \mathrm{~h}$ ). The outdoor temperature shown in Figure 7 went up at 10:00 AM to $32{ }^{\circ} \mathrm{C}$ and reached $42.5{ }^{\circ} \mathrm{C}$ at $12: 30 \mathrm{PM}$. This causes the condenser of the $\mathrm{A} / \mathrm{C}$ unit to start increasing the power consumption. The total power reached to $5.4 \mathrm{~kW}$ when the condenser of the $\mathrm{A} / \mathrm{C}$ unit is connected directly with the compressor supply. On the other hand, when the outdoor temperature reaches $27.5{ }^{\circ} \mathrm{C}$, the compressor $\mathrm{A} / \mathrm{C}$ unit temperature decreases so the condenser power consumption also decreases. In this case, the total power reaches the nominal power of $4.95 \mathrm{~kW}$.

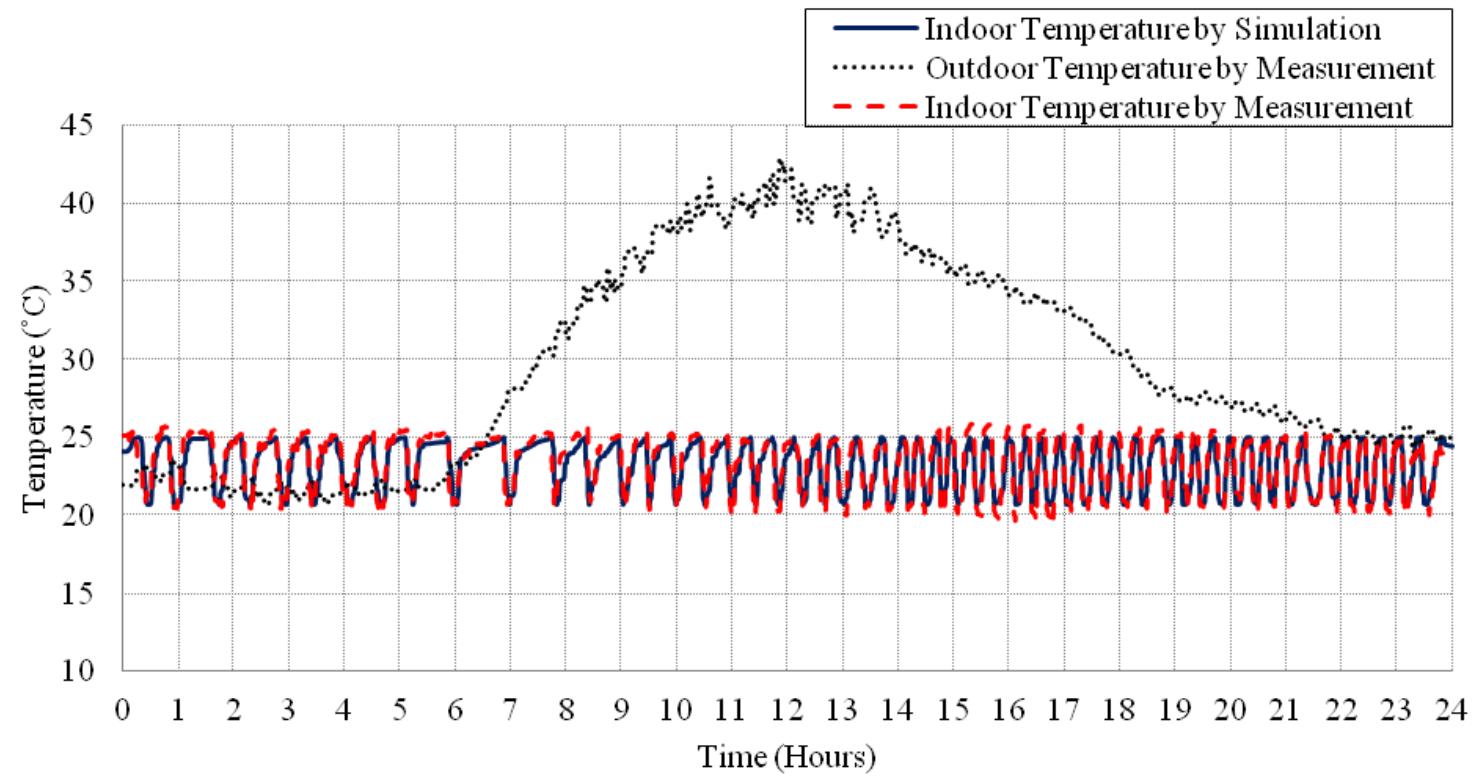

Figure 7. Measured and simulated indoor temperature and the outdoor temperature on $9^{\text {th }}$ of April 2016

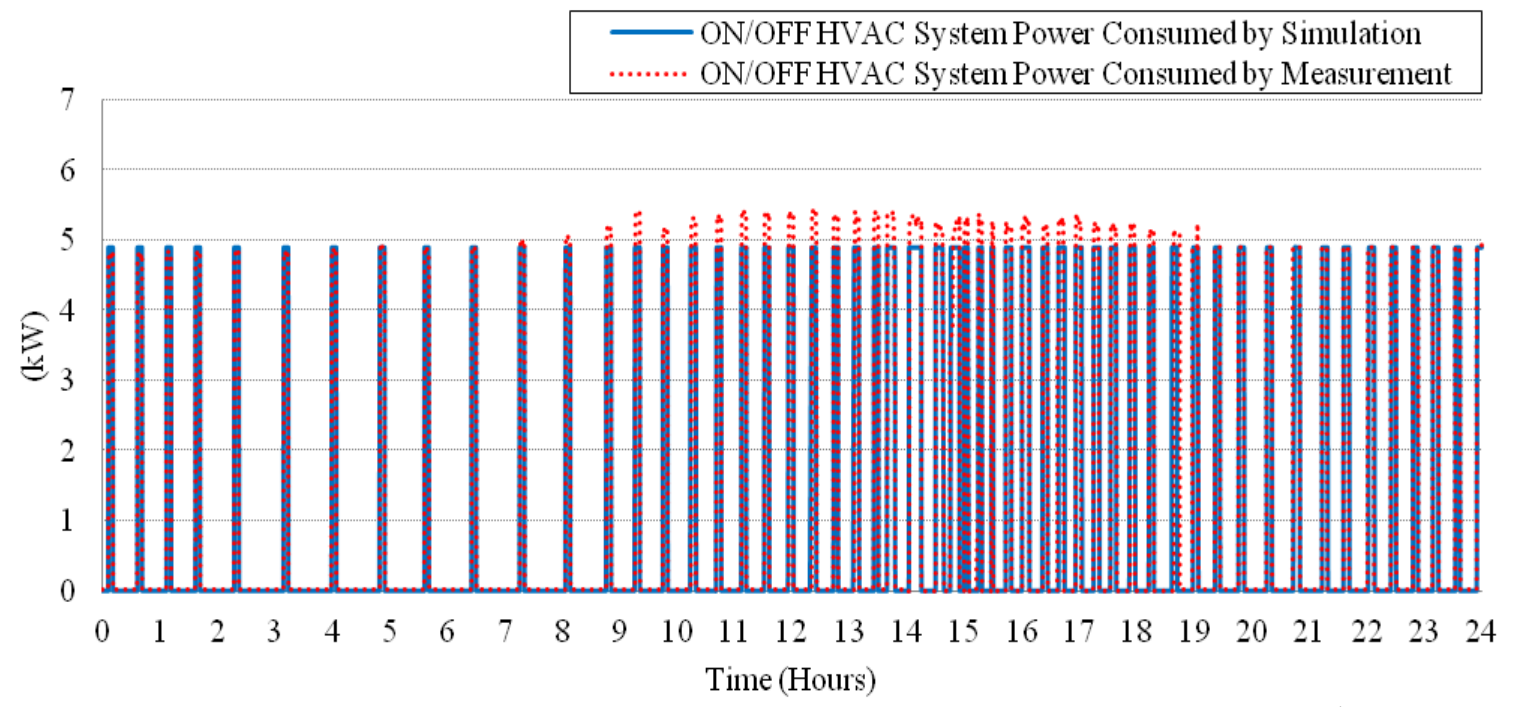

Figure 8. Measured and simulated consuming power for the ON/OFF cycle A/C unit on the $9^{\text {th }}$ of April 2016 


\section{Typical Activities (April 9, 2016) for the VFD A/C Unit}

Similarly, the typical activities validation for the indoor temperature is displayed in Figure 9. The simulated results are similar to those of the measurement, where the temperature for both values is in the same level $\left(24.5{ }^{\circ} \mathrm{C}\right.$ to $23{ }^{\circ} \mathrm{C}$ ). The outdoor temperature and typical activities (permanent and social heat load) have a direct effect on the VFD A/C unit performance, where the amount of flow rate is increased or decreased to match closely the set point temperature $\left(24^{\circ} \mathrm{C}\right)$.

The simulation and measurement of the power consumption for the VFD A/C unit on the $9^{\text {th }}$ of April, 2016 are shown in Figure 10. The power consumption starts to rise at 05:30 AM and reaches a maximum value (1.7 $\mathrm{kW})$ at 10:00 AM until 12:00 PM because of the in-house activities (cooking breakfast/lunch, washing machine, open/close windows and door, etc.), and rise in the outdoor temperature. The power consumption decreases gradually until it reaches $0.9 \mathrm{~kW}$ at 3:00 PM and increases again to $1.3 \mathrm{~kW}$ because of the increase in the in-house activities (cooking dinner, washing machine, open/close door, boiling tea water, etc.). It then goes down to 0.4 kW till 09:00 $\mathrm{PM}$ and finally goes up to $0.9 \mathrm{~kW}$ at midnight.

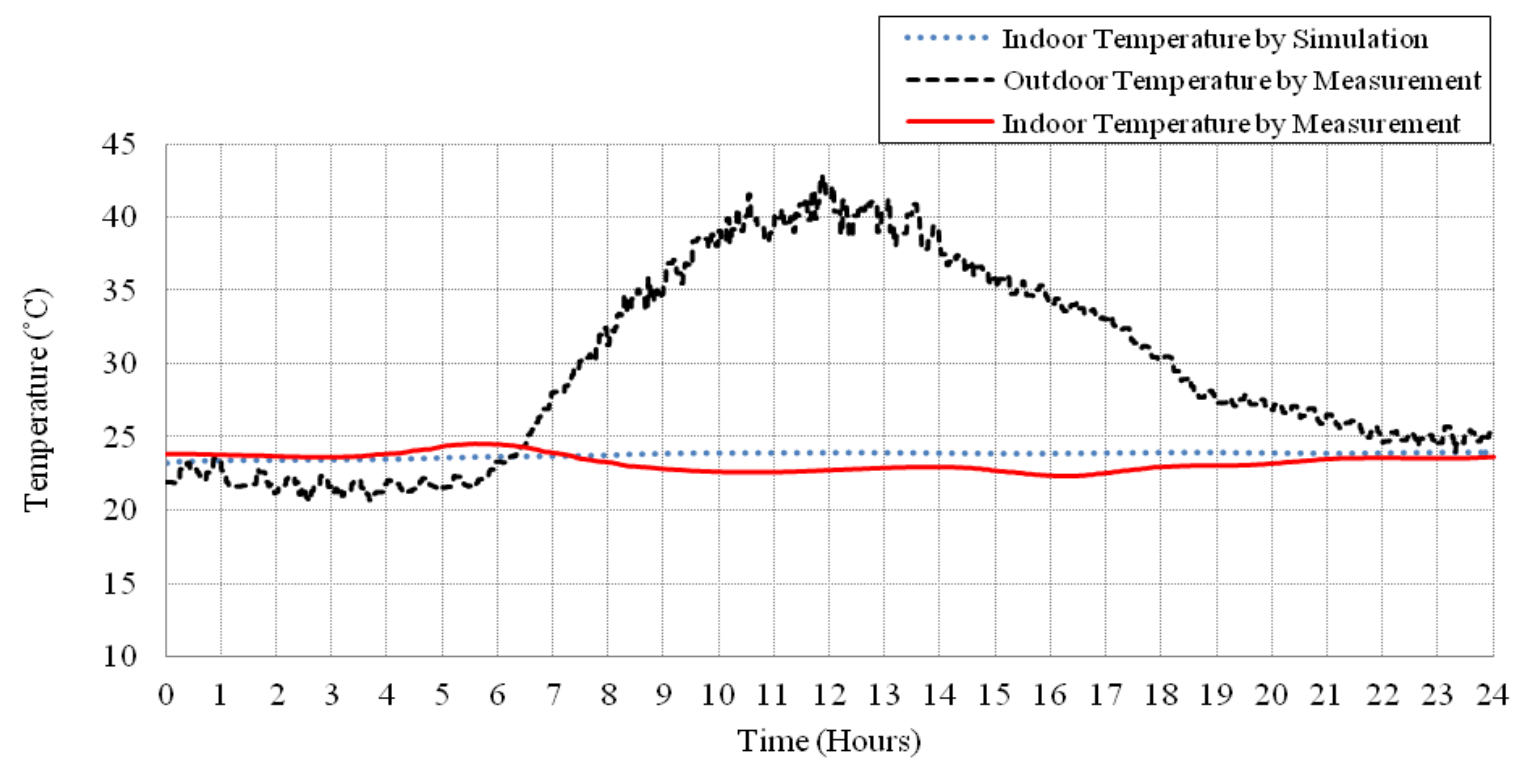

Figure 9. Outdoor measured temperature and indoor measured temperature and indoor simulated temperatures by the VFD HVAC unit on the $9^{\text {th }}$ of April, 2016

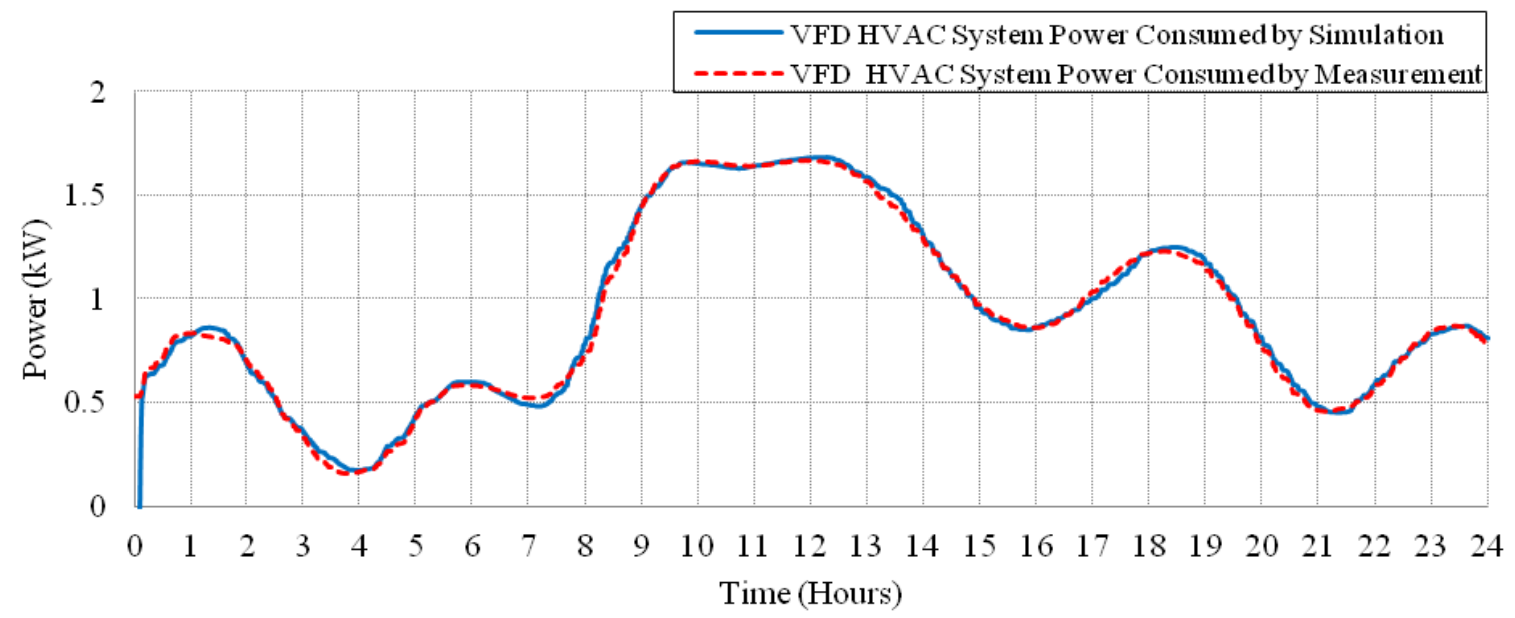

Figure 10. Measured and simulated power consumption for the VFD A/C unit on the 9th of April, 2016 
Journal of Thermal Engineering, Research Article, Vol. 5, No. 3, pp. 181-197, April, 2019

\section{Energy Analysis for Both On/Off Cycle and VFD HVACSystems}

The energy consumption for the ON/OFF cycle and the VFD HVAC units is calculated by integrating the area under power consumption curve as shown in Figures $8 \& 10$ for typical activities $\left(9^{\text {th }}\right.$ of April, 2016) for both simulation results and data measurement. Table 1 shows the energy consumption of both ON/OFF and VFD HAVC for one typical day.

Table 1. Energy analysis for the ON/OFF cycle and the VFD HVAC systems for one day

\begin{tabular}{|c|c|c|c|c|c|c|}
\hline \multirow{2}{*}{ Day } & \multicolumn{3}{|c|}{ Simulated Results } & \multicolumn{3}{c|}{ Measurement Data } \\
\cline { 2 - 6 } & $\begin{array}{c}\text { ON/OFF Cycle Unit } \\
(\mathbf{k W h})\end{array}$ & $\begin{array}{c}\text { VFD Unit } \\
\mathbf{( k W h )}\end{array}$ & $\begin{array}{c}\text { Saving } \\
\mathbf{\%}\end{array}$ & $\begin{array}{c}\text { ON/OFF Cycle } \\
\text { Unit (kWh) }\end{array}$ & $\begin{array}{c}\text { VFD Unit } \\
\text { (kWh) }\end{array}$ & $\begin{array}{c}\text { Saving } \\
\mathbf{\%}\end{array}$ \\
\hline $\begin{array}{c}\text { Typical activities } \\
\text { (April 9, 2016) }\end{array}$ & 37.212 & 22.4 & 39.53 & 38.44 & 23.71 & 38.31 \\
\hline
\end{tabular}

A summary of measured energy consumption for two months (April 2016 and May 2016) that is used for the validation of the simulation results is presented in Table 2. The comparison of the energy consumption for the ON/OFF cycle and the VFD HVAC units and energy savings are also presented in the Table.

Table 2. Comparison energy consumption for the ON/OFF cycle and the VFD HVAC systems for two months, 2016

\begin{tabular}{|c|c|c|c|c|c|c|}
\hline \multirow{3}{*}{ Months } & \multicolumn{3}{|c|}{ Simulated Results } & \multicolumn{3}{c|}{ Measurement Data } \\
\cline { 2 - 7 } & $\begin{array}{c}\text { ON/OFF Cycle Unit } \\
(\mathbf{k W h})\end{array}$ & $\begin{array}{c}\text { VFD Unit } \\
(\mathbf{k W h})\end{array}$ & $\begin{array}{c}\text { Saving } \\
(\boldsymbol{\%})\end{array}$ & $\begin{array}{c}\text { ON/OFF Cycle Unit } \\
(\mathbf{k W h})\end{array}$ & $\begin{array}{c}\text { VFD Unit } \\
(\mathbf{k W h})\end{array}$ & $\begin{array}{c}\text { Saving } \\
\mathbf{\%}\end{array}$ \\
\hline April & 1042.058 & 571.0345 & 45.2012 & 1098.3 & 519.3 & 52.7184 \\
\hline May & 1763.567 & 1038.548 & 41.1109 & 1606.11 & 1130.88 & 29.589 \\
\hline
\end{tabular}

\section{Monthly Variation of Energy Consumption}

Table 3 presents a summary of the results of energy consumption for seven months of study. Both the $\mathrm{ON} / \mathrm{OFF}$ cycle HVAC and the VFD HVAC systems are used with the same conditions. The average operation period of the ON/OFF cycle and the number of ON pulse also are displayed in the table. The energy consumption in $\mathrm{kW}$ is presented for both the ON/OFF cycle and the VFD HVAC systems. The hottest months, June and July, show the higher duty cycle per month. The comparison of the energy consumption for both systems is shown in Figure 11 and the energy savings per month is presented in Figure 12. Table 3 shows that a considerable amount of savings of energy occur from April 2016 to Oct. 2016.

Table 3. Comparison energy used for the ON/OFF and the VFD HVAC systems for several months

\begin{tabular}{|c|c|c|c|c|c|c|c|}
\hline \multirow[b]{2}{*}{ Months } & \multicolumn{4}{|c|}{ ON/OFF Cycle HVAC System } & \multicolumn{3}{|c|}{ VFD HVAC System } \\
\hline & $\begin{array}{c}\text { Numbers } \\
\text { of (ON) } \\
\text { Pulses }\end{array}$ & $\begin{array}{c}\text { The } \\
\text { average of } \\
\text { ON Time } \\
\text { (mins) }\end{array}$ & $\begin{array}{c}\text { The } \\
\text { average of } \\
\text { OFF Time } \\
\text { (mins) }\end{array}$ & $\begin{array}{c}\text { The } \\
\text { average } \\
\text { ON Duty } \\
\text { Cycle (\%) }\end{array}$ & $\begin{array}{c}\text { Energy } \\
\text { used per } \\
\text { Month } \\
(\mathbf{k W h})\end{array}$ & $\begin{array}{c}\text { Energy } \\
\text { used per } \\
\text { Month } \\
\text { (kWh) }\end{array}$ & $\begin{array}{c}\text { Energy } \\
\text { Saving } \\
(\%)\end{array}$ \\
\hline April 2016 & 1450 & 7.0172 & 16.982 & 50.342 & 1042.058 & 571.0345 & 45.2012 \\
\hline May 2016 & 1906 & 11.492 & 12.507 & 53.072 & 1763.567 & 1038.548 & 41.1109 \\
\hline June 2016 & 2190 & 13.500 & 10.499 & 54.15 & 2004.897 & 1329.972 & 33.6638 \\
\hline July 2016 & 2309 & 13.796 & 10.203 & 54.380 & 2117.09 & 1419.172 & 32.9659 \\
\hline Aug. 2016 & 2208 & 13.046 & 10.953 & 53.166 & 2002.028 & 1326.967 & 33.7188 \\
\hline
\end{tabular}

Table 3. (Cont.) Comparison energy used for the ON/OFF and the VFD HVAC systems for several months 
Journal of Thermal Engineering, Research Article, Vol. 5, No. 3, pp. 181-197, April, 2019

\begin{tabular}{|c|c|c|c|c|c|c|c|}
\hline \multirow[b]{2}{*}{ Months } & \multicolumn{4}{|c|}{ ON/OFF Cycle HVAC System } & \multicolumn{3}{|c|}{ VFD HVAC System } \\
\hline & $\begin{array}{c}\text { Numbers } \\
\text { of (ON) } \\
\text { Pulses }\end{array}$ & $\begin{array}{c}\text { The } \\
\text { average of } \\
\text { ON Time } \\
\text { (mins) }\end{array}$ & $\begin{array}{c}\text { The } \\
\text { average of } \\
\text { OFF Time } \\
\text { (mins) }\end{array}$ & $\begin{array}{c}\text { The } \\
\text { average } \\
\text { ON Duty } \\
\text { Cycle (\%) }\end{array}$ & $\begin{array}{c}\text { Energy } \\
\text { used per } \\
\text { Month } \\
(\mathbf{k W h})\end{array}$ & $\begin{array}{c}\text { Energy } \\
\text { used per } \\
\text { Month } \\
\text { (kWh) }\end{array}$ & $\begin{array}{c}\text { Energy } \\
\text { Saving } \\
(\%)\end{array}$ \\
\hline Sep. 2016 & 2150 & 11.732 & 12.267 & 53.333 & 1742.216 & 1142.922 & 34.3983 \\
\hline Oct. 2016 & 1540 & 7.9502 & 16.049 & 51.633 & 1219.962 & 756.8483 & 37.9613 \\
\hline
\end{tabular}

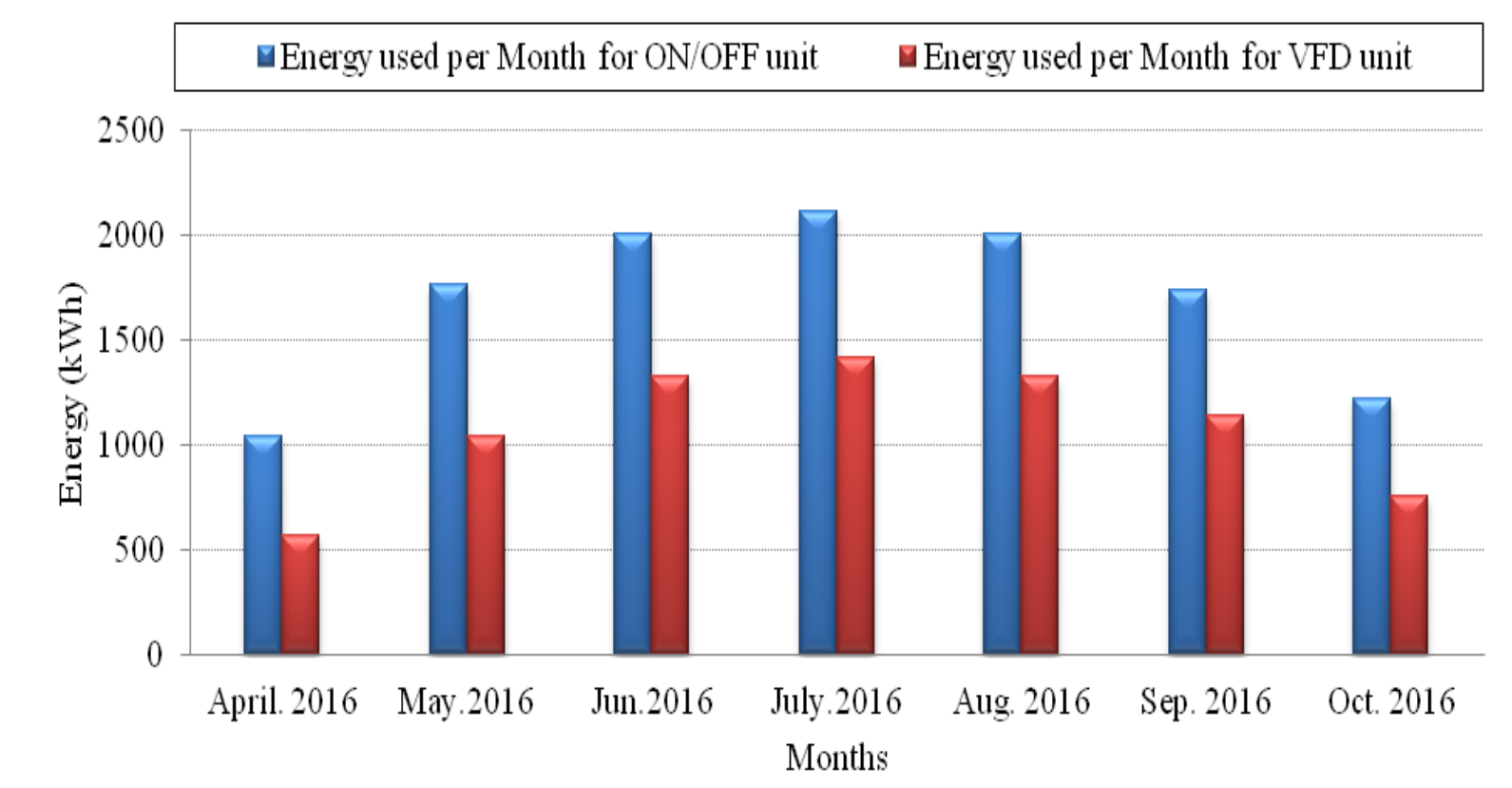

Figure 11. Energy consumption for the ON/OFF cycle and the VFD HVAC system

\section{Monthly Energy Savings}

The energy consumption is the power $(P)$ multiplied with the time of operation $(t)$ of the AC system [22], whereas the percentage of energy savings is calculated based on the difference between energy consumed using the ON/OFF control and energy consumed using the VFD control.

$$
\text { Power }=\frac{\mathrm{V} \times \mathrm{I} \times \mathrm{PF}}{1000}(\mathrm{~kW})
$$

where I is the current (Ampere), $\mathrm{V}$ is voltage (Volts), and PF is the power factor.

$$
\begin{gathered}
\text { Energy }=\text { Power } \times \mathrm{t} \quad(\mathrm{kWh}) \\
\text { Energy Savings }=\frac{[\text { ON/OFF HVAC Energy }]-[\text { VFD HVAC Energy }]}{[\text { ON/OFF HVAC Energy }]} \times 100
\end{gathered}
$$

The energy savings per month is shown in Figure 12. 
Journal of Thermal Engineering, Research Article, Vol. 5, No. 3, pp. 181-197, April, 2019

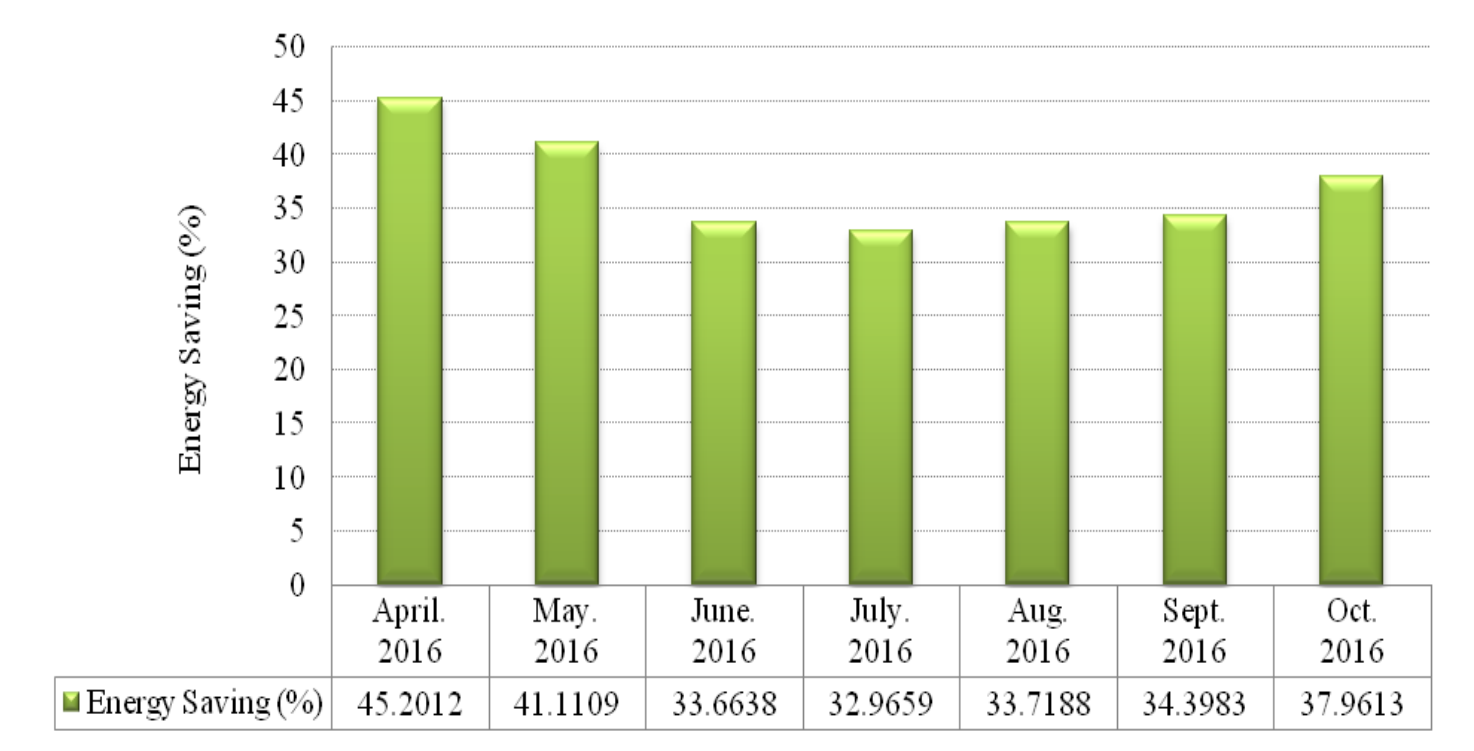

Figure 12. Energy saving rate per month

\section{Average Monthly COP Variations}

The coefficient of performance (COP) is commonly used to express the efficiency of an air-conditioning system [22]. The main purpose of the $A / C$ system is to remove heat or to process load from the evaporator $\left(Q_{L}\right)$. The energy required at the compressor ( $\mathrm{W}_{\mathrm{com}}$ ) is to accomplish the refrigeration effect. Thus, the COP is expressed as:

$$
\mathrm{COP}=\frac{\left(\mathrm{h}_{1}-\mathrm{h}_{4}\right)}{\left(\mathrm{h}_{2}-\mathrm{h}_{1}\right)}=\frac{\mathrm{Q}_{\mathrm{L}}}{\mathrm{W}_{\mathrm{com}}}=\frac{\text { Internal Heat Gain (Energy Input) }(\mathrm{kWh})}{\text { Total Energy Consumption }(\mathrm{kWh})}
$$

where, $h_{1}$ and $h_{2}(\mathrm{~kJ} / \mathrm{kg})$ are the enthalpy at the compressor inlet and that of the compressor outlet, respectively, $h_{4}$ $(\mathrm{kJ} / \mathrm{kg})$ is the enthalpy at the evaporator inlet, $\mathrm{Q}_{\mathrm{L}}(\mathrm{kWh})$ is the refrigerating effect, and $\mathrm{W}_{\mathrm{com}}(\mathrm{kWh})$ is the compression work.

The maximum theoretical COP for the air conditioning system is expressed by Carnot's theorem given by the following equation:

$$
\mathrm{COP}_{\text {Maximum }}=\frac{\left(\mathrm{T}_{\mathrm{C}}\right)}{\left(\mathrm{T}_{\mathrm{H}}-\mathrm{T}_{\mathrm{C}}\right)}
$$

where $\mathrm{T}_{\mathrm{C}}$ is the cold temperature and $\mathrm{T}_{\mathrm{H}}$ is the hot temperature. The air conditioning system cools the house to $22.5^{\circ} \mathrm{C}$ for $(\mathrm{ON} / \mathrm{OFF})$ and $24{ }^{\circ} \mathrm{C}$ for $(\mathrm{VFD})$. If the average outdoor temperature is $35.55^{\circ} \mathrm{C}$ the theoretical maximum COP is:

$$
\mathrm{COP}_{\operatorname{Max}}(\mathrm{ON} / \mathrm{OFF})=\frac{\left(\mathrm{T}_{\mathrm{C}}\right)}{\left(\mathrm{T}_{\mathrm{H}}-\mathrm{T}_{\mathrm{C}}\right)}=1.72
$$


Journal of Thermal Engineering, Research Article, Vol. 5, No. 3, pp. 181-197, April, 2019

$$
\mathrm{COP}_{\operatorname{Max}(\mathrm{VFD})}=\frac{\left(\mathrm{T}_{\mathrm{C}}\right)}{\left(\mathrm{T}_{\mathrm{H}}-\mathrm{T}_{\mathrm{C}}\right)}=2.10
$$

The total internal heat gain for the $9^{\text {th }}$ of April 2016 is calculated based on the solar heat gain, mass heat gain, and the internal house activities in both houses. On the other hand, the monthly average COP variation is calculated based in the measured energy and the internal Heat Gain (April 2016).

The daily average of internal Heat Gain for the month of April for both houses $=42.922 \mathrm{kWh}$

The daily average of energy used for the month of April by the ON/OFF HVAC unit $=36.61 \mathrm{kWh}$

The daily average of energy used for the month of April by the VFD HVAC unit $=20.82 \mathrm{kWh}$

$$
\begin{aligned}
& \mathrm{COP}_{(\mathrm{ON} / \mathrm{OFF})}=\frac{\mathrm{Q}_{\mathrm{L}}}{\mathrm{W}_{\text {com }}}=\frac{42.922 \mathrm{kWh}}{36.61 \mathrm{kWh}}=1.172 \\
& \mathrm{COP}_{(\mathrm{VFD})}=\frac{\mathrm{Q}_{\mathrm{L}}}{\mathrm{W}_{\text {com }}}=\frac{42.922 \mathrm{kWh}}{20.82 \mathrm{kWh}}=2.062
\end{aligned}
$$

\section{Cost Analysis of Both the On/Off and the VFD HVAC System}

The payback period is calculated by counting the number of years it will take to recover the cash invested in installing the VFD HVAC unit instead of the conventional ON/OF HVAC unit. The payback period for setting the temperature to $24^{\circ} \mathrm{C}$ can be calculated by the following formula.

$$
\text { Payback Period }=\frac{\text { Additional Cost }}{\text { Annual Saving }}
$$

The cost difference between the ON/OFF unit and the VFD unit is about 40\% (8750SR) in which the VFD unit is higher cost than the conventional ON/OFF unit.

Based on the calculation performed in Table 4, the payback period is six years and 6 months, so if the user installs a VFD HVAC system, he can recover the extra paid money within 6 years and 6 months. During the time after the payback period, the user will start to get the benefit of having the VFD HVAC in the house as the energy consumption is going to be less than that of having an ON/OFF unit.

Table 4. Payback period for a residential HVAC

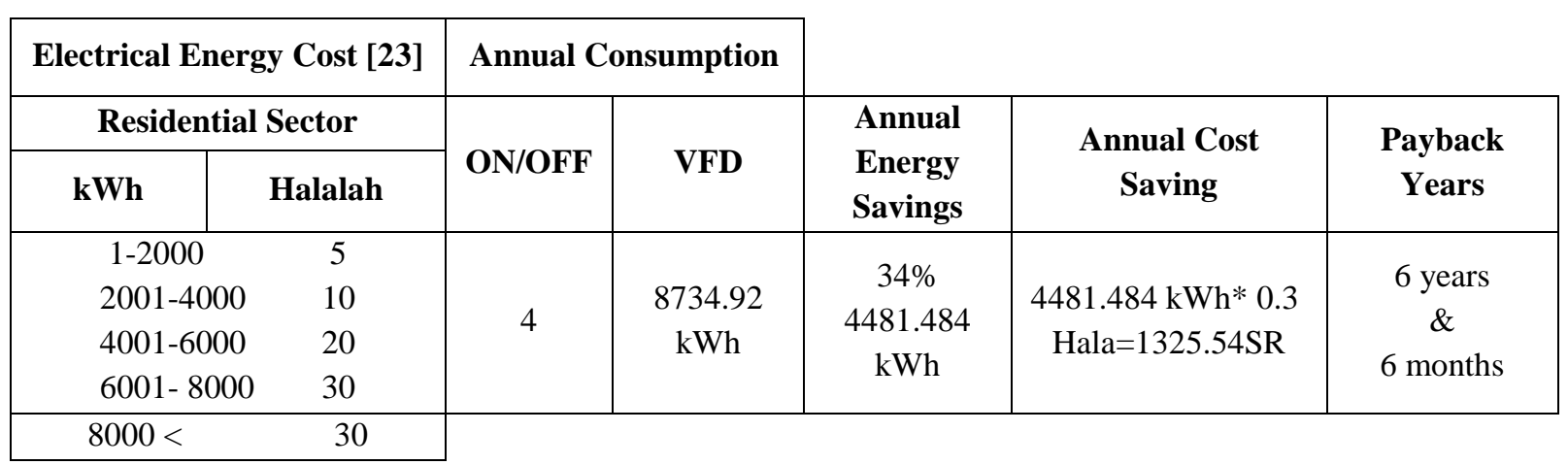

\section{CONCLUSIONS}

The HVAC systems incorporating the ON/OFF controller and the VFD controller are considered to determine the compressor power consumptions for the HVAC unit in residential areas located at the King Fahd University of Petroleum and Minerals campus in the Kingdom of Saudi Arabia. Thermal analysis is carried out in 
line with the experimental conditions to assess the energy consumption of the HVAC system. The experimental setup is developed incorporating the LabVIEW based data acquisition monitoring and measurement system. The thermal model considers different types of A/C system controller (ON/OFF, VFD) units. The predictions of the power consumptions of the HVAC system have been compared with those of the measured data. The developed mathematical thermal house model is integrated with the cooling source model of an ON/OFF cycle and VFD air conditioning systems. The developed thermal models are simulated by using Simscape physical components in Matlab/Simulink environment. In addition, the analysis pertinent to the assessment of energy consumptions, energy savings, and the cost of the payback period have been evaluated. In general, the variable frequency drive controller provides higher efficiency and low cost of $\mathrm{A} / \mathrm{C}$ system. In addition, the specific conclusions derived from the present study are listed as follows:

- The energy consumptions have been examined for several months and it is demonstrated that the energy savings reach between 32\% - 45\% during the period from April 2016 to October 2016. It has been noticed that the performance system simulation is affected by the outdoor temperature and the indoor activities during the day. Energy savings with VFD reached $45 \%$ in a medium outdoor temperature.

- The simulation results matched significantly with the experimental data measurement with an error of about $3 \%$.

- The daily and monthly average COP variations of actual and ideal system are calculated and the findings revealed that VFD unit has higher COP than the ON/OFF cycle.

- The cost analysis and the payback period have been calculated. It is found that the user needs only 6 years and a half to recover the additional cost. In the near future, if there is any further drop in the price of the VFD unit, it will become a catalyst in the promotion of energy conversion through the use of a VFD unit.

- The paper has shown that installing a VFD for a residential HVAC system gives considerable energy savings over the ON/OFF cycle.

\section{ACKNOWLEDGMENT}

The authors acknowledge the support by the DSR funded project RG1205-1\&2 at King Fahd University of Petroleum and Minerals, Dhahran, Saudi Arabia for this research work. Also, the authors acknowledge the donation of two 5-tons A/C systems from the Al-Zamil Air-Conditioning Company, Industrial City, Dammam, Saudi Arabia.

\section{NOMENCLATURE}

\begin{tabular}{|c|c|}
\hline $\mathrm{H}$ & Heat transfer coefficient, $\mathrm{W} / \mathrm{m}^{2} . \mathrm{K}$ \\
\hline $\mathrm{T}_{\text {out }}$ & External house temperature, $\mathrm{K}$ \\
\hline $\mathrm{T}_{\mathrm{H}}$ & Internal house temperature, $\mathrm{K}$ \\
\hline $\mathrm{T}_{1}$ & Internal roof temperature, $\mathrm{K}$ \\
\hline $\mathrm{T}_{2}$ & Internal wall temperature, $\mathrm{K}$ \\
\hline $\mathrm{T}_{3}$ & Internal windows temperature, $\mathrm{K}$ \\
\hline $\mathrm{C}_{\text {Air }}$ & Specific heat of air, $\mathrm{J} / \mathrm{kg}$ \\
\hline $\mathrm{C}_{\text {Roof }}$ & Specific heat of roof, $\mathrm{J} / \mathrm{kg}$ \\
\hline $\mathrm{C}_{\text {Wall }}$ & Specific heat of wall, $\mathrm{J} / \mathrm{kg}$ \\
\hline $\mathrm{C}_{\text {Wind }}$ & Specific heat of window, $\mathrm{J} / \mathrm{kg}$ \\
\hline$Q_{\text {Air }}$ & The rate of energy stored in the volumetric space of the house, $\mathrm{J}$ \\
\hline$Q_{\text {Roof }}$ & The rate of energy stored in the wall, $\mathrm{J}$ \\
\hline Qwall & The rate of energy stored in the roof, $\mathrm{J}$ \\
\hline $\mathrm{Q}_{\text {Wind }}$ & The rate of energy store in the windows, $\mathrm{J}$ \\
\hline $\operatorname{MHVAC}(\mathrm{t})$ & Mass flow rate of supply air, $\mathrm{kg} / \mathrm{s}$ \\
\hline $\mathrm{C}_{\mathrm{P}}$ & Air specific heat, $\mathrm{J} / \mathrm{kg} . \mathrm{K}$ \\
\hline $\mathrm{T}_{\text {House }}$ & In-House temperature, $\mathrm{K}$ \\
\hline $\mathrm{T}_{\text {HVAC }}$ & HVAC coil A/C temperature, $\mathrm{K}$ \\
\hline $\mathrm{K}_{0}$ & The effective cooler gain, $\mathrm{kg} / \mathrm{K}$ (default $\mathrm{K}_{0}=1 \mathrm{~kg} / \mathrm{K}$ ) \\
\hline $\mathrm{K}_{1}$ & The effective time cooler gain, $\mathrm{kg} / \mathrm{s} . \mathrm{K}$ (default $\mathrm{K}_{1}=1 \mathrm{~kg} / \mathrm{s} . \mathrm{K}$ ) \\
\hline $\mathrm{K}_{2}$ & The effective HVAC gain, default $\mathrm{K}_{2}=0.005$ \\
\hline
\end{tabular}


$\mathrm{K}_{3} \quad$ The effective time HVAC gain, $\mathrm{S}^{-1}$ (default $\mathrm{K}_{3}=0.9 \mathrm{~S}^{-1}$ )

$\frac{\mathrm{dQ}_{\text {Cooler }}}{\mathrm{dt}} \quad$ The absorbed heat flow rate by cooler, $\mathrm{J} / \mathrm{s}$

$\mathrm{Q}_{\text {Heat }} \quad$ The heat source, $\mathrm{J}$

House

REFERENCES

[1] Salmi, W., Vanttola, J., Elg, M., Kuosa, M., Lahdelma, R. (2017). Using waste heat of ship as energy source for an absorption refrigeration system. Applied Thermal Engineering, 115, 501-516.

[2] Aly, W. I., Abdo, M., Bedair, G., Hassaneen, A. E. (2017). Thermal performance of a diffusion absorption refrigeration system driven by waste heat from diesel engine exhaust gases. Applied Thermal Engineering, 114, 621630.

[3] Wang, J., Wang, B., Wu, W., Li, X., Shi, W. (2016). Performance analysis of an absorption-compression hybrid refrigeration system recovering condensation heat for generation. Applied Thermal Engineering, 108, 54-65.

[4] Xu, Y., Jiang, N., Wang, Q., Chen, G. (2016). Comparative study on the energy performance of two different absorption-compression refrigeration cycles driven by low-grade heat. Applied Thermal Engineering, 106, 33-41.

[5] Sun, L., Han, W., Jin, H. (2015). Energy and exergy investigation of a hybrid refrigeration system activated by mid/low-temperature heat source. Applied Thermal Engineering, 91, 913-923.

[6] Farsi, A., Mohammadi, S. H., Ameri, M. (2017). Thermo-economic comparison of three configurations of combined supercritical CO2 refrigeration and multi-effect desalination systems. Applied Thermal Engineering, 112, 855-870.

[7] Al-Shaalan, A., Ahmed, W., Alohaly, A. (2014). Design guidelines for buildings in Saudi Arabia considering energy conservation requirements. In Applied Mechanics and Materials (Vol. 548, pp. 1601-1606). Trans Tech Publications.

[8] Salsbury, T., Diamond, R. (2000). Performance validation and energy analysis of HVAC systems using simulation. Energy and buildings, 32(1), 5-17.

[9] Muratori, M., Marano, V., Sioshansi, R., Rizzoni, G. (2012, July). Energy consumption of residential HVAC systems: a simple physically-based model. In 2012 IEEE Power and Energy Society General Meeting (pp. 1-8). IEEE.

[10] Karmacharya, S., Putrus, G., Underwood, C., Mahkamov, K. (2012, June). Thermal modelling of the building and its HVAC system using Matlab/Simulink. In 2012 2nd International Symposium On Environment Friendly Energies And Applications (pp. 202-206). IEEE.

[11] Wen, Y., Burke, W. (2013, April). Real-time dynamic house thermal model identification for predicting HVAC energy consumption. In 2013 IEEE Green Technologies Conference (GreenTech) (pp. 367-372). IEEE.

[12] Zhu, Y. (2006). Applying computer-based simulation to energy auditing: A case study. Energy and buildings, 38(5), 421-428.

[13] Zhou, D., Park, S. H. (2012). Simulation-assisted management and control over building energy efficiency-a case study. Energy Procedia, 14, 592-600.

[14] Yu, J., Yang, C., Tian, L. (2008). Low-energy envelope design of residential building in hot summer and cold winter zone in China. Energy and Buildings, 40(8), 1536-1546.

[15] Nasution, H., Dahlan, A. A., Aziz, A. A., Azmi, U., Sumeru, S., Shodiya, S. (2016). Energy Efficiency of A Variable Speed of The Centralized Air Conditioning System Using PID Controller. Jurnal Teknologi, 78(8-4).

[16] Coley, D. A., Penman, J. M. (1996). Simplified thermal response modelling in building energy management. Paper III: Demonstration of a working controller. Building and environment, 31(2), 93-97.

[17] Hamanah,W.M., (2016), "Modeling, Simulation and Energy Performance of VFD and ON/OFF Cycle HVAC Systems," M.S. thesis, KFUPM, Az Zahran, Saudi Arabia.

[18] Hamanah, W. M., Kassas, M., Mokheimer, E. M., Ahmed, C. B., Said, S. A. M. (2019). Comparison of Energy Consumption for Residential Thermal Models With Actual Measurements. Journal of Energy Resources Technology, 141(3), 032002. 
[19] Ohyama, K., Kondo, T. (2008). Energy- Saving Technologies for Inverter Air Conditioners. IEEJ Transactions on Electrical and Electronic Engineering, 3(2), 183-189.

[20] Ohyama, K., Kondo, T. (2008). Energy- Saving Technologies for Inverter Air Conditioners. IEEJ Transactions on Electrical and Electronic Engineering, 3(2), 183-189.

[21] Belhadj, C. A., Hamanah, W. M., Kassas, M. (2017, June). LabVIEW based real time Monitoring of HVAC System for Residential Load. In 2017 IEEE International Conference on Computational Intelligence and Virtual Environments for Measurement Systems and Applications (CIVEMSA) (pp. 66-71). IEEE.

[22] Affandi, M. (2004). Energy Saving in an Air-Conditioning System Using an Inverter and a Temperature-Speed Controller (Doctoral dissertation, Universiti Teknologi Malaysia).

[23] Council of Ministers, (2016) Consumption Tariff, Saudi Electricity Company, No.95 https://www.se.com.sa/en us/customers/Pages/TariffRates.aspx/ 